\title{
Student Learning Styles in The Industrial Revolution 4.0
}

\author{
Febri Yanti ${ }^{12^{*}}$, Lufri ${ }^{3}$, Yuni Ahda ${ }^{3}$ \\ ${ }^{1}$ Doctoral Program Student, Postgraduate Program, Universitas Negeri Padang, Padang, West Sumatra, Indonesia \\ ${ }^{2}$ Biology Education Program, STKIP PGRI Sumatra Barat, Padang, West Sumatra, Indonesia \\ ${ }^{3}$ Biology Educationa Study Program, Faculty of Mathematics and Natural Sciences, Universitas Negeri Padang, Padang, West Sumatra, \\ Indonesia
}

DOI: 10.29303 /ippipa.v7iSpeciallssue. 972

\section{Article Info}

Received : September 19th, 2021

Revised : December 2nd, 2021

Accepted: December 6 $6^{\text {th }}, 2021$

\begin{abstract}
The industrial revolution 4.0 in the field of education provides convenience in learning methods and processes. Internet-based technology makes it easier for students to learn independently, quickly in providing feedback, and freely choose material from library sources from anywhere. As a result, student learning styles change along with the development of internet-based technology. In the coursework, students can read and combine various writings from several sources, and in-class when students present assignments of learning materials that have been read so that they are easily understood by other students. Likewise, in completing paper assignments from lecturers, students can read various papers given by many lecturers. This happens because of the students' understanding of the assignments given by the lecturer. The purpose of this study was to identify the learning styles of students of the Biology Education Study Program, STKIP PGRI Sumatera Barat on the development of internet-based technology in the industrial revolution 4.0. This type of research is descriptive and the approach used is quantitative. The results of this study indicate that the learning style of students of the Biology Education Study Program STKIP PGRI Sumatera Barat, Padang, West Sumatra tends to be visual, namely $60.3 \%$. The presence of internet technology and its use in an educational institution is a medium or source of learning that can be utilized by students.
\end{abstract}

Keywords: Learning style; Visual; Auditory; Kinesthetic; Industrial revolution 4.0

Citation: $\quad$ Yanti, F., Lufri, L., \& Ahda, Y. (2021). Student Learning Styles in The Industrial Revolution 4.0. Jurnal Penelitian Pendidikan IPA, 7(SpecialIssue), 187-193. https:// doi.org/10.29303/jppipa.v7iSpecialIssue.972

\section{Introduction}

Industrial revolution 4.0 is digital disruption and a digital revolution marked by intelligent engineering, human-machine connectivity, and the internet of things. In the digital revolution, there was the dissemination of communication information tools and advances in the industrial sector (Sasikirani \& Herlambang, 2020). In the industrial revolution 4.0, there was a megatrend due to the transformation of technology and the manufacturing industry through digitization and exploitation of the potential of new technologies in various fields (Schwab, 2016; Rojko,
2017). As a result of the industrial revolution 4.0, automation, mechanization, and digitalization occurred, so that the industrial revolution 4.0, various technological information innovations emerged. The industrial revolution 4.0 in education is a response to technological needs to create new opportunities innovatively and creatively way.

The industrial revolution 4.0 in the field of education makes learning methods and processes easier. The learning process can occur anytime and anywhere, not limited by space and time. Through the internet in the era of the industrial revolution 4.0, everything is digital, internet-based, which is getting

\footnotetext{
*Email: febriyanti1985@yahoo.co.id
} 
faster and all information is unlimited (Cloete, 2018). Internet-based technology makes it easier for students to learn independently, quickly in providing feedback, and freely choose material from library sources from anywhere. Students can access various information without restrictions via the internet and participate in environmental demands and the needs of life (Hardika, et al, 2020; Rahmatih, et al., 2020). As a result, student learning styles change along with the development of internet-based technology. Even in the classroom, when students present assignments, learning materials that have been read are easy for other students to understand. Likewise, in completing paper assignments from lecturers, students can read various papers given by many lecturers. This happens because of the students' understanding of the assignments given by the lecturer. This of course changes various aspects of student learning styles. Learning style is the way that students respond to information, how to remember, think, and solve problems in the learning process (Akram, 2014; Nasution, 2008).

Each student has differences in performance, learning speed, and learning style. Differences in learning styles indicate the easiest way for students to absorb information during learning. Learning style is the way students learn in terms of absorbing, managing, and processing information remembering, reasoning, and/or solving problems obtained from lecturers (Sudria, et al., 2018). Learning style is the key to student success in the learning process. Learning styles play an important role in the learning process and contribute to the success of learning. Student learning styles need to be known by lecturers for effectiveness in learning and students' intellectual abilities as well as facilitating the learning process. The purpose of this study was to identify the learning styles of students of the Biology Education Study Program, STKIP PGRI West Sumatra on the development of internet-based technology in the industrial revolution
4.0. Learning style is the key to student success in the learning process and learning outcomes.

\section{Method}

This type of research is descriptive and the approach used is quantitative. The population in this study were all students of the Biology Education Study Program, STKIP PGRI Sumatera Barat, Padang, Indonesia in the even semester of 2020/2021. The population in this study was 120 people and the number of samples was 58 people.

The sampling technique used is simple random sampling. The learning style questionnaire was compiled based on five forms of learning styles, namely visual, auditory, kinesthetic, visual kinesthetic, and visual kinesthetic auditory (De Poter \& Hernacki, 1999).

The number of statements used in this study was 38 items. The visual learning style questionnaire consists of 11 items, the auditory learning style questionnaire consists of 9 items, the kinesthetic learning style questionnaire consists of 6 items, the visual kinesthetic learning style questionnaire consists of 6 items, and the visual kinesthetic learning style questionnaire consists of 6 items. All statements in the questionnaire are favorable with criteria Strongly Agree $(\mathrm{SA})=4$, Agree $(\mathrm{A})=3$, Disagree $(\mathrm{D})=2$, and Strongly Disagree $(\mathrm{SD})=1$. The data analysis technique in this study is the method of descriptive statistical analysis.

\section{Result and Discussion}

Learning styles play an important role in the learning process and contribute to the success of student learning. The results of the analysis of the five learning styles of students of the Biology Education Study Program, STKIP PGRI Sumatera Barat, Padang, Indonesia can be seen in Table 1.

Table 1. Results of student learning style analysis

\begin{tabular}{llllllll}
\hline No & Learning style & Average & $\begin{array}{l}\text { Standard } \\
\text { deviation }\end{array}$ & $\begin{array}{l}\text { Number of } \\
\text { valid items }\end{array}$ & N & $\begin{array}{l}\text { Maximum } \\
\text { value }\end{array}$ & $\begin{array}{l}\text { Minimum } \\
\text { value }\end{array}$ \\
\hline 1 & Visual & 5.27 & 3.27 & 11 & 58 & 10 & 1 \\
2 & Auditorial & 58.26 & 4.52 & 9 & 58 & 10 & 1 \\
3 & Kinesthetic & 3.76 & 3.86 & 6 & 58 & 10 & 1 \\
4 & Visual kinesthetic & 4.27 & 4.56 & 6 & 58 & 10 & 1 \\
5 & Visual kinesthetic Auditorial & 2.35 & 2.76 & 6 & 58 & 10 & 1 \\
\hline
\end{tabular}

The results of the analysis of the five learning styles of students of the Biology Education Study Program, STKIP PGRI, West Sumatra, Padang
Indonesia, were obtained through filling out questionnaires by students (Figure1). 

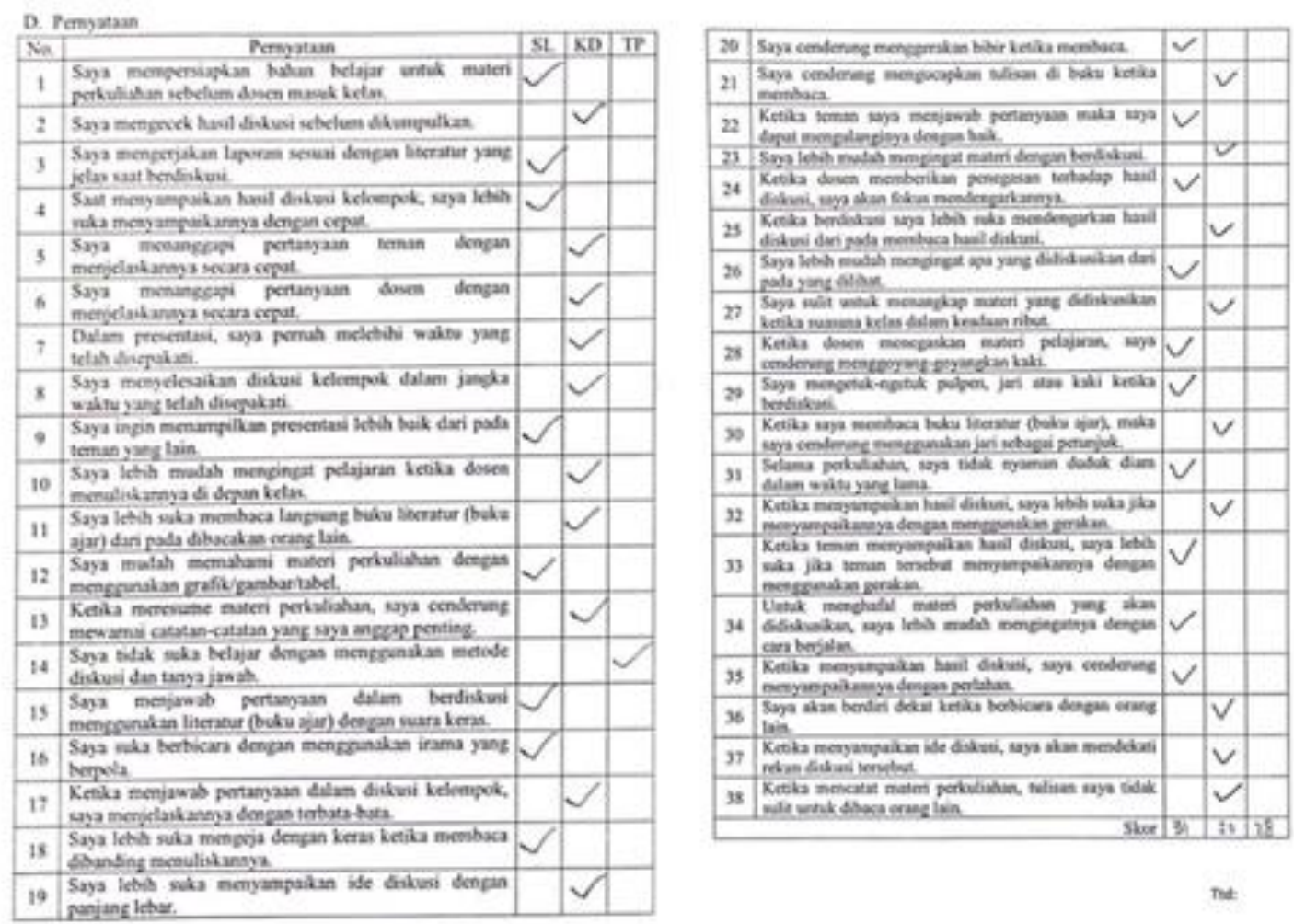

a) Student learning style questionnaire

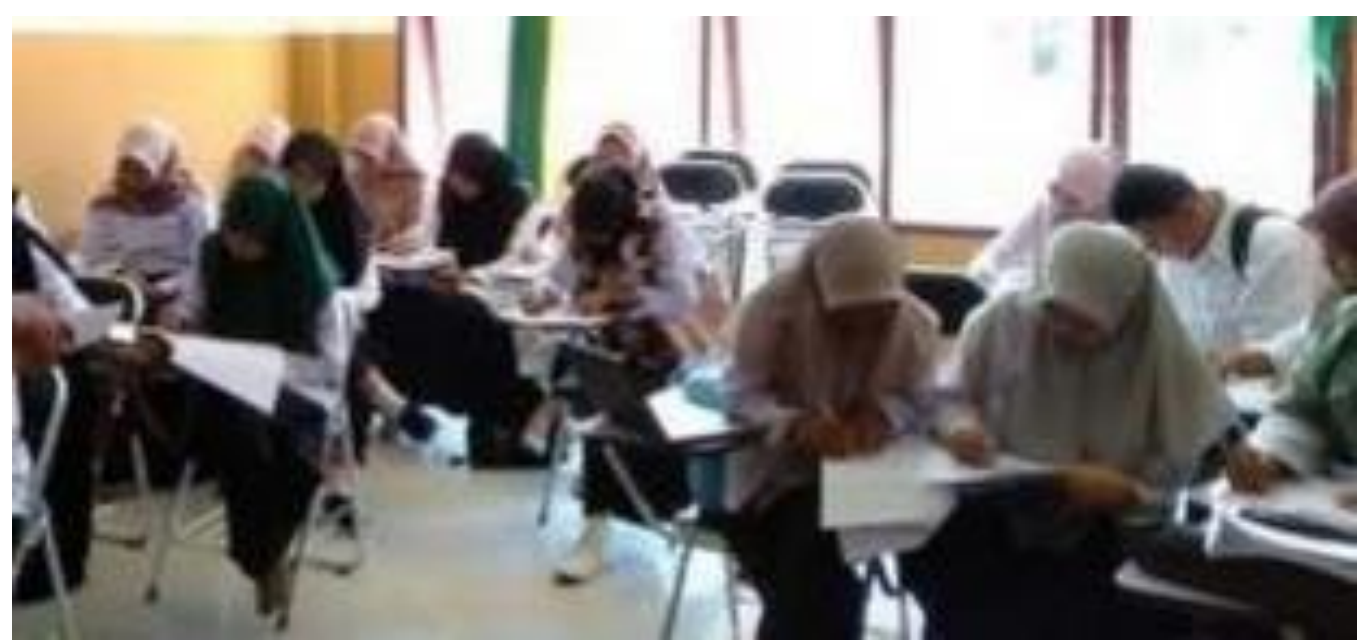

b) Students fill out a learning style questionnaire

Figure 1. Analysis of the five learning styles of students was obtained through filling out questionnaires by students

Based on Table 1, it can be seen the average value and standard deviation of the five student learning styles. In the visual learning style, the average value is 5.27 and the standard deviation is 3.27 . The mean value of auditory learning style is 58.26 and the standard deviation is 4.52 . The average value of the kinesthetic learning style is 3.76 with a standard deviation of 3.86 . The average value of the visual-kinesthetic learning style is 4.27 with a standard deviation of 4.56 . The average value of the visual-auditory kinesthetic learning style is 2.35 with a standard deviation of 2.76 .
The maximum score from the analysis of student learning styles is 10 and the minimum score is 1 .

Frequency and percentage of students' learning style tendencies, namely 34 people or $60.3 \%$ of students with visual learning style, 12 people or $20.7 \%$ with auditory learning style, 10 people or $15.5 \%$ with kinesthetic learning style, 1 person or $1.7 \%$ with visualkinesthetic learning style, and 1 person or $1.7 \%$ with visual-auditory-kinesthetic learning style (Table 2). 
Table 2. Frequency and percentage of student learning styles

\begin{tabular}{lllll}
\hline $\begin{array}{l}\text { Visual } \\
\text { (people) }\end{array}$ & $\begin{array}{l}\text { Auditorial } \\
\text { (people) }\end{array}$ & $\begin{array}{l}\text { Kines } \\
\text { thetic } \\
\text { (people) }\end{array}$ & $\begin{array}{l}\text { Visual- } \\
\text { kinesthetic } \\
\text { (people) }\end{array}$ & $\begin{array}{l}\text { Visual- } \\
\text { auditorial- } \\
\text { kinesthetic } \\
\text { (people) }\end{array}$ \\
\hline 34 & 12 & $\begin{array}{l}10 \\
\text { Percentage }(\%)\end{array}$ & 1 \\
60.3 & 20.7 & 15.5 & 1.7 & 1.7 \\
\hline
\end{tabular}

The result of this study shows that students' learning styles tend to be visual, which is $60.3 \%$ (Table 2). Students with visual learning styles are easier to remember, understand, and enjoy things based on their eyesight (De Poter \& Hernacki, 1999). The characteristic of visual learning style is being able to see and observe (Gantasala \& Gantasala, 2009). Visual learning style has a good sense of sight and the eyes can receive any stimulus to see. The results of the same study show that 120 students of the Tarbiyah Study Program, State Islamic Institute, Ternate, Indonesia tend towards visual learning styles (Jamulia, 2018). In contrast to the results of the research by Papilaya \& Huliselan, (2016), there are 20 students of the Counseling Guidance Study Program, Pattimura University, Indonesia with an auditory learning style. The results of research conducted by Yazici (2005); Harvey et al., (2010) show that a person's learning style is not determined by the learning experience and the field of study he is studying.

This visual learning style is used by students of the Biology study program of STKIP PGRI Sumatera Barat in completing tasks given by the lecturer during the learning process. Through the ability of this visual learning style, students understand the subject matter. Even in the classroom, when students present assignments, learning materials that have been read are easy for other students to understand. Likewise, in completing paper assignments from lecturers, students can read various papers given by many lecturers. This happens because of the students' understanding of the assignments given by the lecturer. In addition, it is easy to access various information through internet-based technology.

Internet-based technology in the industrial revolution 4.0 has developed in the world of education and provides innovative learning methods and processes. Industrial revolution 4.0 focuses on the movement of the digital literacy economy, created intelligence, big data, robotics. The era of disruptive innovation occurs along with the rapid development of technology (Schmidt \& Druehl, 2008). Internet-based technology makes it easier for students to learn independently, quickly in providing feedback, and freely choose material from library sources from anywhere. Students can access various information without restrictions through internet-based technology (Rahmatih, et al., 2020).

Technological developments can improve learning methods so that they develop to form informal education. Various forms of e-learning developed in the 4.0 industrial revolution, such as online courses, Coursera, phet.com, and MOOCs). Student learning style is one of the factors that determine the success of the learning process (Kamuche, 2011; Wilkinson et al., 2013; Kaminiski, et al., 2005). Applied Kolb's Learning Style Inventory and found a significant level of relation between grades and learning style.

In the field of learning, the process of collaboration between experts has now been realized. Many learning materials (including interactive ones) are presented by education experts to several websites that can be used by anyone, without having to pay (of course the user must honestly state who the compiler is). The presence of information and communication technology in the form of the internet has brought convenience in the implementation of educational activities, especially for needs to improve learning at all levels of education, especially education in universities. The presence of internet technology and its use in an educational institution is a medium or source of learning that can be utilized by students (Kaliky, 2013). According to Fleming, et al. (2011) states that "student learning styles change as the classroom environment changes.

The number of students with auditory learning styles is $20.7 \%$, which means that students cannot understand the learning material if the environment around the study area is noisy. The opinion of De Poter \& Hernacki, (2000) is that the auditory learning style is more dominant in using the sense of hearing to carry out learning activities. Students who have an auditory learning style tend to have difficulty reading material when the environment around the class is crowded, cannot concentrate if there is a commotion, and cannot even focus on learning if there is music playing at a large volume. This is because students with auditory learning styles are more likely to use their ears as a medium of learning so that if other sounds come from outside the focus of their study, they will not be able to concentrate on learning. Auditory learners gain information through aural channels such as verbal discussions and listening to others' speeches. These learners understand meaning by concentrating on the pitch, tone, and speed of the voice.

Students get information from reading aloud without using written information. Teachers cannot change students' learning styles in the classroom, but teachers can modify students' learning styles more consistently. Teachers can approach the appropriate 
teaching style so that teachers can overcome various problems of student learning styles. According to James and Gardner, (1995) learning style is the way students understand, process, store, and remember the learning provided by the teacher.

The kinesthetic learning style possessed by students is $15.5 \%$, meaning that students have a kinesthetic learning style tendency, cannot remember material by rote, prefer to touch physically when talking to other people, even speak very slowly when presenting in class. The student likes movement and works with touchable objects. They enjoy regular breaks and move around the room (Oxford, 2001). Learning style plays a significant role in the lives of learners. When students recognize their learning style, they will be able to integrate it into their learning process.

The visual-kinesthetic learning style of students is $1.7 \%$, which means that students are happy with the combination of these two learning styles. Students are happy with how to read the subject matter and read the assignments given by the lecturer. In addition, students can not remember the material by rote, prefer to touch physically when talking to other people. Learning is a fundamental element of people's everyday lives. Learning experiences can take the form of our interactions with others, through attending an educational establishment, etc. Every student has a different way of learning and learning style. One student with other students learns in different ways. Through e-learning, students must be able to adapt to the learning style of internet based-learning (Widharyanto \& Binawan, 2020).

The visual-auditorial-kinesthetic learning style of students is $1.7 \%$ where students are happy with the combination of these three learning styles. Students like to read, listen, and do not like to memorize subject matter. Students with a combination of these three learning styles generally have good learning outcomes compared to students who only have one learning style. The transformation in learning and the mindset of millennial students is changing according to the digital transformation in industrial revolution 4.0 which can improve learning outcomes. The changes from the meaning of learning that so far have only been based on academic numerical orientation are no longer expected and are always the main goal of millennial learners (Hardika et al., 2020). The meaning of learning for them participates in changing according to the demands of the environment and the necessities of life. Learning must further inspire the millennial generation that currently exists at a high level of education to be able to rise and be motivated to increase the capacity to manage themselves and the environment in which they live, not just fulfilling intellectual capacity.

\section{Conclusion}

The industrial revolution 4.0 there was a megatrend due to the transformation of technology and the manufacturing industry through digitization and exploitation of the potential of new technologies in various fields. Internet-based technology makes it easier for students to learn independently, quickly in providing feedback, and freely choose material from library sources from anywhere. As a result, student learning styles change along with the development of internet-based technology. Even in the classroom, when students present assignments, learning materials that have been read are easy for other students to understand. Likewise, in completing paper assignments from lecturers, students can read various papers given by many lecturers. There are 34 students or $60.3 \%$ of students with visual learning styles, 12 people or $20.7 \%$ with auditory learning styles, 10 people or $15.5 \%$ with kinesthetic learning styles, 1 person or $1.7 \%$ with kinesthetic visual learning style, and 1 person or $1.7 \%$ with kinesthetic visual-auditory learning style. This means that the learning style of students of the Biology Education Study Program STKIP PGRI Sumatera Barat, Padang, West Sumatra tends to be visual, namely $60.3 \%$.

\section{Acknowledgment}

The research team would like to thank the head of STKIP PGRI Sumatera Barat for allowing the research to be carried out. Thank you to students and colleagues who have helped in the research and writing of this article.

\section{References}

Akram Awla, H. (2014). Learning Styles and Their Relation to Teaching Styles. International Journal of Language and Linguistics, 2(3), 241. https://doi.org/10.11648/j.ijl1.20140203.23

Aoun, J.E. (2018). Robot-proof: higher education in the age of artificial intelligence. US: MIT Press.

Biabani, M., \& Izadpanah, S. (2019). The Study of The Relationship between Kolb's Learning Styles, Gender, and Learning American Slang by Iranian EFL Students. International Journal of Instruction, 12(2), 517-538. https://doi.org/10.29333/iji.2019.12233

Boström, L., \& Hallin, K. (2012). Learning Style Differences between Nursing and Teaching Students in Sweden: A Comparative Study. International Journal of Higher Education, 2(1). https://doi.org/10.5430/ijhe.v2n1p22

Cloete, A. (2018). Technology and Education: 
Challenges and Opportunities. October 2017. https://doi.org/10.4102/hts.v73i3.4589

De Poter, B. \& Hernacki, M. (2000). Quantum learning. Yogyakarta: Kaifa.

Engels, P. T., \& De Gara, C. (2010). Learning Styles of Medical Students, General Surgery Residents, and General Surgeons: Implications for Surgical Education. BMC Medical Education, 10(1). https://doi.org/10.1186/1472-6920-10-51

Fleming, N. D., \& Mills, C. (1992). Not Another Inventory, Rather A Catalyst for Reflection. To Improve The Academy, 11(1), 137-155. doi: https://doi.org/10.1002/J.23344822.1992.Tb00213.X

Gantasala, P. V., \& Gantasala, S. B. (2009). Influence of Learning Styles. International Journal of Learning, 16(9), 169-184. https://doi.org/10.18848/14479494/cgp/v16i09/46612

Gholami, S., \& Bagheri, M. S. (2013). Relationship between VAK Learning Styles and ProblemSolving Styles Regarding Gender and Students' Fields of Study. Journal of Language Teaching and Research, 4(4), 700-706. doi: https:// doi.org/10.4304/jltr.4.4

Hamzah, (2008). Orientasi Baru dalam psikologi pembelajaran. Jakarta: PT Bumi Aksara [Indonesian]

Hardika, Aisyah, E. N., Raharjo, K. M., \& Soraya, D. U. (2020). Transformation of the Meaning of Learning for The Millennial Generation in The Digital Era. International Journal of Interactive Mobile Technologies, 14(12), 69-81. https://doi.org/10.3991/IJIM.V14I12.15579

Harvey, D., Ling, C., \& Shehab, R. (2010). Comparison of student's learning style in STEM disciplines. IIE Annual Conference and Expo 2010 Proceedings, 2010.

Jamulia, J. (2018). Identifying Students Learning Style Preferences At IAIN Ternate. International Journal of Education, 10(2), 121-129. https://doi.org/10.17509/ije.v10i2.1631

James, W.B. \& Gardner, D.L. (1995). Learning Styles: Implications for Distance Learning. New Directions for Adult and Continuing Education, 67, 19-31. https://doi.org/10.1002/ace.36719956705

Kaliky, P. I. (2013). Pemanfaatan Internet dalam Pembelajaran Mahasiswa di Universitas Pattimura, Ambon. Jurnal Komunika KAREBA, 2(1), 110-120. https://doi.org/10.31947/kjik.v2i1.354 [Indonesian]

Kaminski, D. A., Théroux, P. J., Lister, B. C., \& Gabriele, G. A. (2005). Exploring the Link between Student Learning Styles \& Grades in an Introductory Thermal-Fluids Course. In Proceedings of The 2005
American Society For Engineering Education Annual Conference \& Exposition (Pp. 10.508.1-10.508.16). American Society for Engineering Education

Kamuche, F. U. (2011). Do Learning \& Teaching Styles Affect Students Performance? An Empirical Study. Journal of Business \& Economics Research (JBER),3(9).

Doi: https://doi.org/10.19030/Jber.V3i9.2806

Lujan, H. L., \& DiCarlo, S. E. (2006). First-year medical students prefer multiple learning styles. Advances in physiology education, 30(1), 13-16. https://doi.org/10.1152/advan.00045.2005

Nasution, S. (2008). Berbagai pendekatan dalam proses belajar dan mengajar. Jakarta: Bumi Aksara [Indonesian]

Oxford, R. (2001) Language Learning Styles and Strategies. In. M. Celce-Murcia, Ed. Teaching English As A Second Or Foreign Language (3 Rd Ed.). US A: Heinle \& Heinle. Retrieved from: http://www.sciepub.com/reference/78657

Orlich, D., Harder, R., Callahan, R., Trevisan, M., \& Brown, A. (2012). Teaching strategies: A guide to effective instruction. Cengage Learning.

Papilaya, J. O., \& Huliselan, N. (2016). Identifikasi Gaya Belajar Mahasiswa (Identify Student Learning Styles). Jurnal Psikologi Undip, 15(1), 56. https://doi.org/10.14710/ipu.15.1.56-63

Puriwat, W., \& Tripopsakul, S. (2020). Preparing for Industry 4.0-will Youths have Enough Essential Skills?: an evidence from Thailand. International Journal of Instruction, 13(3), 89-104. https://doi.org/10.29333/iji.2020.1337a

Rahmatih, A., \& Fauzi, A. (2020, September 30). Persepsi Mahasiswa Calon Guru Sekolah Dasar dalam Menanggapi Perkuliahan secara Daring Selama Masa Covid-19. MODELING: Jurnal Program Studi PGMI, 7(2), 143-153. https://doi.org/https://doi.org/10.36835/mod eling.v7i2.618 [Indonesian]

Sasikirani, V \& Herlambang, Y.T. (2020). Urgensi Merdeka Belajar Di Era Revolusi Industri 4.0 dan Tantangan Society 5.0 E-Tech, 8(2): 1-8. https://doi.org/10.24036/et.v8i2.110765 [Indonesian]

Schwab, K. (2016). The fourth industrial revolution. Geneva: World Economic Forum

Schmidt, G. M., \& Druehl, C. T. (2008). When Is A Disruptive Innovation Disruptive? Journal of Product Innovation Management, 25(4), 347-369. https://Doi.Org/10.1111/J.15405885.2008.00306.X

Sudria, I. B. N., Redhana, I. W., Kirna, I. M., \& Aini, D. (2018). Effect of Kolb's Learning Styles under Inductive Guided-Inquiry Learning on Learning Outcomes. International Journal of Instruction, 
11(1),

89-102.

https://doi.org/10.12973/iji.2018.1117a

Susilo, M. Joko. (2006). Gaya belajar menjadikan makin pintar. Yogyakarta : Pinus. [Indonesian]

Widharyanto, B., \& Binawan, H. (2020). Learning Style and Language Learning Strategies of Students from Various Ethnicities in Indonesia. Cakrawala Pendidikan, 39(2), 480-492. https://doi.org/10.21831/cp.v39i2.28173

Wilkinson, T., Boohan, M., \& Stevenson, M. (2013). Does Learning Style Influence Academic Performance in Different Forms of Assessment? Journal Of Anatomy, 224(3), 304-308. doi: https://doi.org/10.1111/Joa.12126

Yahya, M. (2018). Era Industri 4.0: Tantangan dan Peluang Perkembangan Pendidikan Kejuruan Indonesia. Orasi Ilmiah Professor bidang Ilmu Pendidikan Kejuruan Universitas Negeri Makassar Tanggal 14 Maret 2018. [Indonesian]

Yazici, H. (2005). A study of collaborative learning style and team learning performance. Education $\mathcal{E}$ Training, 47 , 216-229. https://doi.org/10.1108/00400910510592257 